\title{
Vlaamsche Paedagogiek
}

Progressive educationalists and the construction of a Flemish Volksgemeinschaft, 1922-1944.

Sarah Van Ruyskensvelde \& Marc Depaepe

Introduction

In May 1941, two Belgian progressive educationalists, Jozef Emiel Verheyen and Leo Roels, published a new educational journal, Vlaamsche Paedagogiek (Flemish Pedagogy). The journal aimed to contribute to the development and proliferation of a pedagogy that rooted in the Flemish soil and in the (Flemish) national character. The editors were convinced that "the strong personality only flourishes in its own environment, supported by its own language. Education should be rooted in and permeated by the Flemish spirit". ${ }^{1}$ As this quotation suggests, the journal demonstrated a clear and strong commitment to the Flemish cultural emancipation battle. The editors, Roels and Verheyen, were well-known within the Flemish movement, a $19^{\text {th }}$ and $20^{\text {th }}$ century nationalistic movement that championed the promotion of Flemish culture, language and history in a society that was dominated by French. However, the history of the Flemish movement during the Second World War remains a sensitive issue. As a result of Flemish-nationalist collaboration during the First World War (referred to as aktivisme in Dutch), a strong anti-Belgian wing appeared during the interwar years, demanding Flemish political independence. This radicalization process went hand-in-hand with the total rejection of parliamentary democracy and was accompanied by the proliferation of fascist ideas. ${ }^{2}$

In an effort to abolish the Belgian state, some Flemish nationalists got involved in the collaboration with the German occupier during the Second World War. Among those 'radical' Flemish nationalists were well-known educators. Herman De Vleeschauwer, for instance, had been a member of the Vlaamsche Opvoedkundige Vereeniging (Flemish Association for Education, VOV) during the interwar years. During the 1930s and the Second World War, he became the educational ideologue of the Vlaams Nationaal Verbond (Flemish Nationalist Union, VNV), a political organization that collaborated with the German occupier. He advocated an educational reform on Flemish nationalist grounds. ${ }^{3}$ Parallel to some other pro-German education reformers

\footnotetext{
${ }^{1}$ Jozef-Emiel Verheyen, Leo Roels and A. Gobbers, "Ter inleiding," Vlaamsche Paedagogiek 1, no. 1 (1941): 1.

2 See, for instance, Lode Wils, Van Clovis tot Happart. De lange weg van de naties in de Lage Landen (Leuven/Apeldoorn: Garant, 1992). For a good English introduction to the history of the Flemish movement, see Kas Deprez and Louis Vos, Nationalism in Belgium: Shifting Identities, 1780-1995 (Houndmills: Macmillan, 1998).

3 See, for instance, Olaf Moens, Frank Simon and Jeffrey Tyssens, "'De dag van de opvoeders is nu op komst": onderwijshervormingsvoorstellen rond de Tweede Wereldoorlog," in De Tweede Wereldoorlog als factor in de onderwijsgeschiedenis/La Seconde Guerre mondiale, une étape dans I'histoire de l'enseignement, ed. M. Depaepe and
} 
of the time ${ }^{4}$, he put a strong emphasis on intuition, will power and physical education in schools, rather than on intellectual formation. ${ }^{5}$

The aim of this article is to discuss the position of the Flemish progressive education movement, in particular, during the Second World War, by presenting a case-study of Vlaamsche Paedagogiek, an educational journal that appeared monthly between 1941 and 1944. The existing scholarship about the history of the progressive education movement, or even about Jozef Emiel Verheyen, mentions Vlaamsche Paedagogiek in a cursory way, but failed to give a more detailed description of the journal's aims. The review of Belgian educational periodicals, published in the 1970s by Maurits De Vroede, for instance, discusses Vlaamsche Paedagogiek only briefly. There are quite some studies about the life and work of Jozef Emiel Verheyen, but these do not focus on his involvement in Vlaamsche Paedagogiek, in particular. ${ }^{6}$ As a result, Vlaamsche Paedagogiek

D. Martin (Brussel: Navorsings- en Studiecentrum voor de Geschiedenis van de Tweede Wereldoorlog, 1997), 17-61; Rik Bostoen and Olaf Moens, "Herman De Vleeschauwer," in Nieuwe Encyclopedie van de Vlaamse Beweging, ed. R. De Schryver et al. (Tielt: Lannoo, 1998), 3513-3515.

${ }^{4}$ Examples are, for instance, Remigus Van Mieghem and Filip De Pillecyn. Together with Herman De Vleeschauwer, they were important pro-German staff members of the Ministry of Public Education during the war. Van Mieghem was appointed inspector general for primary education, and had already demonstrated his pro-German sympathies during the First World War. Apart from his beliefs in the unification of the Belgian education system that resembled the German policy of Gleichschaltung, he was the founder of a Dietse pedagogical study group that swore loyalty to the Führer. See: Maurits De Vroede et.al., Bijdragen tot de geschiedenis van het pedagogisch leven in België in de $19^{\text {de }}$ en 20 ste eeuw. Deel 4, Tweede Stuk: De Periodieken 1914-1940 (Leuven, Katholieke Universiteit Leuven - Seminarie voor Historische Pedagogiek, 1973), 1675-7; Karel De Clerck, "The 'Dietsch Opvoedkundige Beweging' in Flanders," in Values in Education: topical issue in honour of Prof. dr. M.-L. Van Herreweghe, ed. M. Spoelders (Gent: Rijksuniversiteit Gent, 1988), 258-66. Filip De Pillecyn, in his turn, was appointed deputy secretary for secondary education. Almost immediately after the German attack in May 1940, he became a member of the VNV, as well as the Deutsch-Vlämische Arbeitsgemeinschaft (German-Flemish Working Group, DeVlag). In his capacity as official within the Ministry, he issued many undemocratic and anti-Semitic circular letters, and actively engaged in propaganda for the battle against Communism. De Pillecyn fiercely criticized the traditional education system, for it focused too much on intellectualism and knowledge transfer alone. See: Anton Van Wilderode, J.L. De Belder, Fernand Van de Velde, Koenraad De Meulder (eds.), 100 jaar Filip De Pillecyn (Gent: Academia Press, 1992); Lammert Buning and Karen Van Hoorick, "Filip De Pillecyn," in Nieuwe Encyclopedie van de Vlaamse Beweging, 2477-9.

${ }^{5}$ Frank Seberechts, "Geheel het schoolstelsel in dienst van de volksgemeenschap'. Filip De Pillecyn als directeur van het Middelbaar Onderwijs (1941-1944)," Filip De Pillecyn Studies 3 (2007): 113.

${ }^{6}$ Relevant publications include: Marc Depaepe, Frank Simon and Angelo Van Gorp, "The 'Good Practices' of Jozef Emiel Verheyen - Schoolman and Professor of Education at the Ghent University. A Case of Using Educationnally Correct Discourse at the Right Place and the Right Time," in Educational Research: Why 'What Works' Doesn't Work, ed. P. Smeyers and M. Depaepe (Dordrecht: Springer, 2006), 17-36; Marc Depaepe, Frank Simon and Angelo Van Gorp, "Reformpädagogik im Dienste der Anpassung an die moderne, bürgerliche Gesellschaft. Niedere und höhere Pädagogik beim Flämischen Schulmann und Hochschullehrer Jozef Emiel Verheyen," in Bildung und Öffentlichkeit. Jürgen Oelkers zum 60. Geburtstag, ed. R. Casale and R. Horlacher (Weinheim/Basel: Beltz Verlag, 2007), 178-191; Marc Depaepe, Kristof Dams and Frank Simon, "'La vie et l'école". Analyse du discours rénovateur de Joseph Emile Verheyen," Bildungsforschung 
remains a somewhat forgotten journal in the Belgian history of (progressive) education, which is presumably a result of the sensitive nature of its explicit Flemish-nationalist character. After the war, Jozef Emiel Verheyen, distanced himself from the journal. He stated that he had never taken the initiative, and that, in fact, it had been the publisher, Haseldonckx, who had asked him to publish the journal, a request he claimed to have initially rejected. ${ }^{7}$ Also Leo Roels does not mention his activities as an editor of the journal in his autobiography. ${ }^{8}$ Hence, the question arises as to what the purposes of the journal were, which educational reforms it advocated and whether it showed similarities with fascist pedagogical principles. As early as 1941, Albert Van Boghout, the chief editor of the Maandblad voor Volkse Opvoeding (Journal for Popular Education), the official journal of the collaborating Dietsche Opvoedkundige Beweging (Diets Educational Movement, DOB) explicitly asked Verheyen to reveal which side he was on. ${ }^{9}$ Apparently, the Flemish cultural emancipation discourse of Vlaamsche Paedagogiek differed from the radical national socialist aspirations of the DOB. ${ }^{10}$

Belgian scholarship has not paid much attention to the relationships between National Socialist Pedagogy and the progressive education movement. ${ }^{11}$ Studies have mainly focused on the relationships between Catholic, normative and National Socialist pedagogy, in particular. Depaepe et al., for instance, has described their relationship as a 'forbidden fruit'. Catholics had no choice but to reject Nazi pedagogy in principle, but at the same time, they admired many principles that

und Bildungspraxis/Education et Recherche/ Educazione e ricerca. Schweizerische Zeitschrift für Erziehungswissenschaft/ Revue suisse des sciences de l'éducation/ Rivista svizerra di scienze dell'educazione XXI, no. 1 (1999) : 9-32.

${ }^{7}$ Marc Depaepe, Frank Simon and Angelo Van Gorp, "Pedagogische Praat. Over het discours van de schoolman Jozef Emiel Verheyen," in 'Over het mooie en het nuttige': bijdragen over de geschiedenis van opvoeding en onderwijs: liber amicorum aangeboden aan Mark D’hoker, ed. M. Depaepe et. al. (Antwerpen: Garant, 2008), 184.

8 In his autobiography, Twintig jaar boeman, Roels seeks to justify his position during the Second World War. In spite of the fact that he held an important position in the Belgian government during the Second World War, he denied any political engagement in favor of the New Order. See: Leo Roels, Twintig jaar Boeman (Tielt: Van In, 1966).

${ }^{9}$ In his Paedagogische Encyclopaedie that Verheyen published together with Casimir, Verheyen wrote a ten-page article about Germany pedagogy. From this, it becomes clear that Verheyen kept all options open. First, he stuck to a rather factual description of the most important characteristics of National Socialist pedagogy. Second, he remains very vague as to what he expected from National Socialism, underlining that "it is too early to assess these thorough, incomplete efforts of reform (...). Also in the field of pedagogy, National Socialism has transformed Germany into a field of trial, from which a whole new education must grow in response to its political ideals and corresponding to a world view that is in direct conflict with the principles of democratic countries, whose results and consequences cannot yet be overlooked and remain a point of interest for every unbiased viewer". See: Jozef-Emiel Verheyen, "Duitsland," in Paedagogische Encyclopaedie, ed. J.-E. Verheyen and R. Casimir (Antwerpen: De Sikkel, 1939), 388-9.

10 Depaepe, Simon and Van Gorp, "Pedagogische Praat," 184.

${ }^{11}$ Internationally, most scholarship about the ambiguous relationships between progressive education and facism has focused on Germany and Italy. For a recent publication on Germany, see, for instance, Peter Dudek, "Reformpädagogik und Nationalsozialismus," in Handbuch Bildungsreform und Reformpädagogik, ed. Barz, H. (Wiesbaden: Springer, 2018), 55-64. For Italy, see, for instance, Hélène Leenders, Der Fall Montessori. Geschichte einer reformpädagogischen Erziehungskonzeption im italienischen Faschismus (Bad Heilbrunn: Klinhardt, 2001). 
coincided with Catholic pedagogy, such as the focus on authority, discipline and specific gender roles. $^{12}$

The progressive education movement, however, embraced modernity, so the connections with traditionalist, anti-democratic or even Fascist organizations in education remain somewhat problematic. Perhaps, this is especially true for Belgium, where some teachers of L'Ermitage, the progressive school established by one of Belgium's leading progressive educationalists, Ovide Decroly, joined the resistance and published a clandestine journal. Decroly himself was a freemason, and cherished liberal and even leftist beliefs and intrinsically opposed Catholicconservative ideals. ${ }^{13}$ As a result, the historiography of the Second World War has not paid much attention to the relationships between progressive educationalists and fascist pedagogies. Rather, it focused on collaborating organizations, such as the DOB, as prototypical examples of antimodern educational reform in Flanders. ${ }^{14}$

Similar to Depaepe and Dams, who concluded that he discourse of some progressive educationalists was similar to the New Order rhetoric ${ }^{15}$, we argue that the discourse of Vlaamsche Paedagogiek showed many similarities with fascist pedagogy, which equally emphasized the importance of education in the construction of a strong Volksgemeinschaft. ${ }^{16}$ However, in spite of those similarities, and its emphasis on notions of character formation, discipline and the Heimat, the journal never explicitly allied itself with the German occupation or National Socialism. In many ways, Flemish progressive educators - such as Verheyen - were children of their time, and the authoritarian didactics of the 1920s and 1930s was to some extent appropriated in a child-centered

\footnotetext{
12 Marc Depaepe, "Katholische und nationalsozialistische Pädagogik in Belgien, 1919-1955. Ihre ambivalente Beziehung im Spiegel der "Vlaamsch Opvoedkundig Tijdschrift" Zeitschrift für Pädagogik 44, no. 4 (1998): 504-522.

${ }^{13}$ For more details on the life and work of Ovide Decroly, see Sylvain Wagnon, De Condorcet à Decroly: La francmaçonnerie belge, l'éducation et l'enseignement (XIXe-XXe) (Bruxelles: Peter Lang, 2018); Angelo Van Gorp, Tussen mythe en wetenschap. Ovide Decroly (1871-1932) (Leuven: Acco, 2005); Angelo Van Gorp, Frank Simon and Marc Depaepe, "Van vele markten thuis: Ovide Decroly (1871-1932)," in Pedagogische historiografie. Een socio-culturele lezing van de geschiedenis van opvoeding en onderwijs, ed. A. Van Gorp et. al. (Leuven/Den Haag: Acco, 2011), 193212; Marc Depaepe, Frank Simon and Angelo Van Gorp, "The Canonization of Ovide Decroly as a "saint" of the New Education," History of Education Quarterly XLIII, no. 2 (2003): 224-249.

${ }^{14}$ See, for instance, De Vroede et.al., Bijdragen tot de geschiedenis van het pedagogisch, 1675-7; De Clerck, The 'Dietsch Opvoedkundige Beweging', 258-266.

${ }^{15}$ See Marc Depaepe (ed.), Order in Progress: everyday educational practice in primary schools, Belgium, 1880-1970 (Leuven: Leuven University Press, 2000); Marc Depaepe, Kristof Dams and Frank Simon, "'La vie et l'école”. Analyse du discours rénovateur de Joseph Emiel Verheyen," Bildungsforschung und Bildungspraxis/Education et Recherche/Educazione e ricerca. Schweizerische Zeitschrift für Erziehungswissenschaft/Revue Suisse des sciences de l'éducation/Riviste svizerra di scienze dell'educazione 21, no. 1 (1999): 9-32.

${ }^{16}$ In a recent article, Heinze and Straube-Heinze, discuss how the cult of heroism and the idea of the Volksgemeinschaft were important aspects of National Socialist indoctrination of children in German schools. See: Carsten Heinze and Kristin Straube-Heinze, "Heroism and Volksgemeinschaft (ethnic community) in National Socialist education 19331945," Paedagogica Historica 53, no. 1 (2017): 115-136.
} 
pedagogical rhetorics. ${ }^{17}$ This contribution documents that Vlaamsche Paedagogiek was in fact a continuation (but perhaps a more radical one?) of the progressive educational discourse of the 1920s and 1930s, expressed in - for instance - the Schoolblad voor Vlaanderen (School journal for Flanders) and Moderne School (Modern School), two journals that were equally edited by Verheyen. However, under the impulse of the occupation, the discourse did gradually shift in the direction of a more explicit Flemish cultural emancipation discourse. Whereas Moderne School put central the Flemish history and culture, and the Dutch language ${ }^{18}$ to establish a school that was closer to reality, in Vlaamsche Paedagogiek, these principles gained a deeper educational meaning for the cultural emancipation of the Flemish Volksgemeinschaft.

A Modern School for Flanders: Jozef Emiel Verheyen, Leo Roels and the Flemish Association for Education, 1920s - 1940s

Vlaamsche Paedagogiek was a continuation of a number of educational journals, edited by Jozef Emiel Verheyen. Verheyen, born in Kessel (Flanders) in May 1889, graduated in 1908 from the Teacher Training College of Mechelen. However, his career in education was rather short, as it was interrupted by the First World War. During the war, he worked in a school for Belgian refugee children in Le Touquet/Paris-Plage (France). It was only after the war, that he, as a student in the Educational Sciences, got in contact with Ovide Decroly and Jean Demoor at the Ecole Supérieure de Pédagogie in Brussels. After his graduation in 1921, he obtained his degree as a cantonal inspector. After a short career as an inspector for primary education, he went to study at the Institut Jean-Jacques Rousseau in Geneva, where he got under the influence of Edouard Claparède. ${ }^{19}$

As an inspector for primary education, Verheyen was a member of the Vlaamsche Opvoedkundige Vereeniging (VOV), an educational association founded in 1922 by Edward Peeters ${ }^{20}$. The association aimed at "the practice of the educational science among its members; the dissemination of educational knowledge among the people; the promotion of the application of

\footnotetext{
17 See: Depaepe, Simon and Van Gorp, "Pedagogische Praat," 182.

${ }^{18}$ It is important to note that the standard language in Flanders is Dutch. 'Flemish' is a variety of Dutch, or dialect, that is used in Flanders, the Northern part of Belgium.

${ }^{19}$ Ann Bories, "Vernieuwend pedagoog of kind van zijn tijd? Het leven en werk van Jozef Emiel Verheyen" (master's thesis, Katholieke Universiteit Leuven, 2002), 2-4; Depaepe, Simon and Van Gorp, "Pedagogische Praat," 171-172.

${ }^{20}$ Edward Peeters (1873-1937) was a Flemish teacher and educational reformer. During his life, he maintained close relationships with, amongst others, Jan Ligthart in the Netherlands. Apart from his activities in education as a teacher, Peeters wrote children's literature. For more details about the life and work of Edward Peeters, see, for instance, Karel De Clerck, "Edward Peeters (1873-1937). Oostends onderwijzer in Oostburg," Biekorf (2011): 153-161; Myriam Gielen, "Edward Peeters en de Nieuwe Schoolbeweging in België voor 1914" (master's thesis, Katholieke Universiteit Leuven, 1983).
} 
educational principles in all branches of education". ${ }^{21}$ Hilaire Deman, the secretary of the association, later indicated that "in spite of the fact that, as such, the VOV never expressed itself in favor of new trends in pedagogy, there was ample opportunity for the supporters of those new ideas to communicate their beliefs and findings to a sympathetic audience". ${ }^{22}$ As follows from the proceedings of the first meeting of the VOV, the organization aimed to bring together educators and pedagogues from different ideological and political corners. ${ }^{23}$ As a result, the VOV did not represent any particular political, ideological or educational movement, but the association does demonstrate an openness to the principles of progressive education. ${ }^{24}$

Already from the very beginning, the VOV supported some of the aims of the Flemish movement. In 1923, for instance, its members passed a motion in favor of the Dutchification ${ }^{25}$ of the University of Ghent, which had - since long - been a demand of the Flemish movement. ${ }^{26}$ The Dutchification of the university certainly was a controversial issue at the time: during the First World War, the German occupier had Dutchified the university, in an effort to find (Flemish) support for the German regime. After the war, its supporters were accused of aktivisme, or collaboration with the German government. During the interwar years, these accusations continued to be a source of latent discontent among Flemish nationalists, which pushed some of them to collaborate with the German occupier during World War II. ${ }^{27}$

Some of those former aktivisten were active in the VOV and knew Verheyen. Between 1924 and 1926, Verheyen chaired the editorial board of the Schoolblad voor Vlaanderen, the official publication medium of the VOV, together with Jan Grauls and Johan Theo Strauven, who were both engaged in the collaboration during the Second World War. Strauven had been involved in the VOV from the very beginning. Between 1922 and 1928 he was the chairman and, after 1928, he continued to play an active role in the organization. Strauven was a convinced Flemish-nationalist school inspector, who promoted the use of Dutch in education. ${ }^{28}$ Also Jan Grauls was active in the

\footnotetext{
${ }^{21}$ See: Jan Van Buggenhout, Enkele aspecten van de pedagogiek in verband met de Vlaamse openbare lagere school, periode 1919-1940 (Gent: Rijksuniversiteit Gent. Hoger Instituut voor Opvoedkundige Wetenschappen, 1961), 37-38. 22 Ibid., 44.

${ }^{23}$ Handelingen der eerste vergadering van de Vlaamsche Opvoedkundige Vereeniging (Brussel: Libertas, 1922), 13-28.

${ }^{24}$ Van Buggenhout, Enkele aspecten van de pedagogiek, 44.

${ }^{25}$ In Belgium, the Dutchification refers mainly to the replacement of French as the dominant language in education, in the administration and in the justice system. The Dutchification of society was an important part of the demands of the Flemish movement. When Belgium gained independence in 1830, Belgian society rapidly Frenchyfied. More specifically, Dutch was banned from higher education, and French became the dominant language in politics and in the justice system. During the $19^{\text {th }}$ and $20^{\text {th }}$ centuries, the Flemish movement aimed to reverse this situation.

${ }^{26}$ Bories, "Vernieuwend pedagoog", 4-6; Van Buggenhout, Enkele aspecten van de pedagogiek, 44.

27 For more information about the Dutchification of the University of Ghent, in the framework of the German Flamenpolitik during the First World War, see Lode Wils, Flamenpolitik en aktivisme. Vlaanderen tegenover België in de Eerste Wereldoorlog (Leuven: Davidsfonds, 1974).

${ }^{28}$ Depaepe et. al., Orde in vooruitgang, 95.
} 
VOV. In 1938, he became director of the Belgian administration of higher and secondary education and maintained close contacts with the Vlaams Nationaal Verbond. ${ }^{29}$ During the Second World War, he held several official positions within the government. For instance, he was President of the Commission for the Revision of School Manuals that was tasked to purge passages in Belgian textbooks that were unfriendly towards the Reich, the Führer or National Socialism. ${ }^{30}$

Hence, many Flemish progressive educators were convinced flamingants. As such, they aimed at the advancement of Flemish in education, and supported the Flemish cultural emancipation project. ${ }^{31}$ Already in 1925, Verheyen referred to the development of a new, Flemish pedagogy:

"If we truly want to educate the child, i.e. prepare it for its later life, to make its adaptation to the needs of life, we must look for a new pedagogy that takes into accounts those needs, we must also look for means to implement this new pedagogy. Next to general demands, that reveal themselves not only in our schools, but with equal vigor in all civilized countries, there are more specific demands that only apply to Flanders, and that necessitate a Flemish pedagogy that roots in our own soil and take into account the particular Flemish situation." 32

This reference to the development of a specific Flemish pedagogy should be framed within a larger evolution. Whereas in the first half of the 1920s, most contributions in the Schoolblad voor Vlaanderen dealt with the position of Dutch in Flemish schools and with linguistic 'abuses', in particular, the linguistic issue and Flemish cultural emancipation battle became a real educational subject towards the end of the 1920s. ${ }^{33}$

This engagement of Flemish progressive educationalists in favor of the cultural emancipation of Flanders via the school regularly surfaces in Moderne School (Modern School), a pedagogical periodical edited by Verheyen between January 1, 1927 and April 1941.34 The title of the journal, 'Modern School', truly exemplifies Verheyen's pedagogical project. Rather than establishing a 'new school', which would have to happen against the background of a 'new society', Verheyen contented himself with the achievements of modern society. In spite of the fact that he aimed to

\footnotetext{
${ }^{29}$ Bernard Van Causenbroeck, "Jan Grauls," in Nieuwe Encyclopedie van de Vlaamse Beweging, 1252-3.

${ }^{30}$ For more details on the Commission of the Revision of School Manuals, see: Kristel De Smedt, "De herziening van de schoolboeken tijdens de bezetting (1940-1944)," Bijdragen tot de Geschiedenis van de Tweede Wereldoorlog 14 (1991): 177-202.

${ }^{31}$ Educational reform in Flanders was deemed necessary, especially as a result of the advancements made in child psychology and the changed societal context after the First World War. The journal discussed initiatives of foreign progressive educators, in an attempt to inspire Flemish teachers to change their didactical methods and educational practices. Bories, "Vernieuwend pedagoog", 21-23.

${ }^{32}$ Cited in Ibid., 25-26.

${ }^{33}$ Ibid., 28.

${ }^{34}$ Ibid., 61.
} 
be the 'heir' of Decroly (at least as far as his discourse is concerned), he never envisaged the establishment of a school that was radically new. Instead, his educational views continued along the lines of the achievements of the past. As a result, the school even became 'more schoolish' as it was entirely included in modern society. ${ }^{35}$

In 1938, Leo Roels joined Moderne School as an editor. Roels, born in December 1882 in Antwerp, was a Catholic and had been working as a cantonal inspector in the 1920s and early 1930s. At the time he joined the editorial board, he worked as an inspector-general for primary education in Brussels. Verheyen appreciated Leo Roels, especially as a 'man of practice' (like himself) rather than a theoretician. According to Verheyen, "Leo Roels belongs to a generation of young pedagogues that, in the 1920s and 1930s have changed the face of Belgian Pedagogy" ${ }^{36}$ With that, he referred to Roels' involvement in the curriculum reform for primary education of 1936 . The reform was a result of the progressive reform tendency in Belgian education. It introduced a rationalization of the curriculum and put a stronger emphasis on 'active observation' in the first two grades of the primary school, in particular. ${ }^{37}$ One of the most important 'innovations' ${ }^{38}$ of the reform probably was the introduction of the Decrolyian centers of interest: a consistent set of subject matters that could be realized during a longer time frame, and that revolved around a central theme attuned to the direct experiences or environment of the child. The idea behind the curriculum reform was to bring schools 'closer to reality', and move away from passive, encyclopedic intellectual education into the direction of observation, association and expression of the subject matter. ${ }^{39}$

As a result, Moderne School endorsed the principles of progressive education: it aimed at the advancement of a scientific pedagogy, and favored individualized education to facilitate children's active participation in the classroom. The journal criticized the traditional school for merely focusing on intellectual education, and emphasized the importance of esthetic education, manual

\footnotetext{
${ }^{35}$ For more details about the relationship between the relationship between the school and modern society in the works of Jozef Emiel Verheyen, see: Marc Depaepe, Frank Simon and Angelo Van Gorp, "Reformpädagogik im Dienste der Anpassung an die moderne, bürgerliche Gesellschaft. Niedere und höhere Pädagogik beim Flämischen Schulmann und Hochschullehrer Jozef Emiel Verheyen," Bildung und Öffentlichkeit. Jürgen Oelkers zum 60. Geburtstag, ed. R. Casale and R. Horlacher (Weinheim/Basel, Beltz Verlag, 2007), 178-191.

${ }^{36}$ Leo Roels and Rommert Casimir, Paedagogische Encyclopaedie. Deel II (Antwerpen: De Sikkel, 1949), 443.

${ }^{37}$ Mark D’hoker and Erik Van Assche, "Lichamelijke opvoeding in het katholiek onderwijs: een lange weg, een moeilijk parcours," in Voor Lichaam en Geest. Katholieken, lichamelijke opvoeding en sport in de $19^{\text {de }}$ en $20^{\text {ste }}$ eeuw, ed. M. D’hoker, R. Renson and J. Tolleneer (Leuven: Universitaire Pers Leuven, 1994), 74; Mark Depaepe, Maurits de Vroede and Frank Simon, "The curriculum reform in Belgian primary education," Journal of Education Policy 6 (1991): $371-383$. 38 The innovatory character of the curriculum of 1936 has been nuanced by Depaepe et al. They demonstrated that the centres of interest, as an educational principle, were already included in the model program for primary education of 1922. See: Depaepe, Orde in Vooruitgang, 94-95.

39 Ibid., 97.
} 
labor and character formation to instill children with a community feeling. ${ }^{40}$ According to the authors and editors of the journal, there was still a lot that needed to be done in order to establish a strong sense of community in Flanders. In order to do so, the journal underlined the importance of Dutch language instruction, history education and children's literature. Firstly, popular art received an important position in the curriculum. More specifically, children needed to be taught love and respect for the popular art and songs, literature and folklore, since these were determining factors of the Flemish Volksgemeinschaft. Secondly, as far as the language of instruction was concerned, Moderne School supported the battle of the Flemish Movement for a correct use of the Dutch language in education, and it rejected bilingual education. ${ }^{41}$ Again, the position of the Dutch language was a measure for the state of Flemish civilization:

"If the Flemish people, from the lower to the higher social strata, have the urge and the ability - where it fits - to express themselves in a pure, graceful, clear and civilized language, then our cultural battle will enter a delightful stage and then our language will command respect in our country, where it is now often considered as immature, and as a carrier of an immature civilization". ${ }^{42}$

Thirdly, Moderne School demanded that more attention needed to be paid to patriotic history: it was imperative that children got to know and learn the glorious history of Flanders. Even before the war, they defended history education on grounds of the Heimat principle. More specifically, the journal argued that history education needed to instill children with a love for the local community and the Flemish fatherland. ${ }^{43}$

In short, the function of the school in the cultural civilization process of Flanders was a recurrent theme in Moderne School. From this follows that the journal supported the traditional battle of the Flemish movement in demanding more rights and respect for Flanders. The Flemish were unique, it was argued, because of their imaginative abilities, in particular, so education needed to contribute to raising consciousness of kinship. ${ }^{44}$ Already at the end of the 1930s, this attachment to the Flemish cause resulted in a stronger plea for the development of a specific Flemish pedagogy. In the final issue of 1941, Verheyen concluded that, in spite of the fact that the reform of educational praxis in Flanders had been achieved by the implementation of the curriculum reform of 1936, it remained unfinished. In May 1941, the time had come to develop "a pedagogy

\footnotetext{
40 Bories, "Vernieuwend pedagoog", 69, 71 and 73.

${ }^{41}$ Bossuyt, "Ik hou zoveel van u", 3-9.

${ }^{42}$ Cited in Ibid., 7.

43 Ibid., 185-186.

44 Ibid., 184-185.
} 
that will root in our own soil, relies upon the national character of the Flemish people and answers to the specific needs of Flanders". ${ }^{45}$

\section{Education must root in the Volksgemeinschaft: an analysis of Vlaamsche Paedagogiek}

As the previous section shows, the Flemish progressive education 'movement' was closely intertwined with the Flemish movement. Moderne School, in particular, was a flamingant journal that demanded attention for the Flemish culture, history, art and language, but they put their Flemish sympathies always in service of progressive educational reform. More specifically, with its emphasis on the specificity of Flanders, the journal intended to bring the school closer to reality. ${ }^{46}$ Vlaamsche Paedagogiek, however, connected more explicitly with the Flemish movement, and the principles of progressive education became just another tool in the construction of a strong Flemish Volksgemeinschaft.

This particular evolution towards a stronger connection to the Flemish cultural emancipation battle is visually illustrated by the front covers of the two journals. ${ }^{47}$ The cover of Moderne School depicts a modernistic building, as an illustration of the journal's engagement for a progressive educational reform and the adaptation of the school to modern society. (See: illustration 1) In contrast, the front cover of Vlaamsche Paedagogiek depicts a rather traditional educational setting: we see an open book with a picture of a mother and her child on the left page, and a teacher and his pupils sitting on school desks and looking at a wall chart. Furthermore, the cover page prominently depicts the Flemish lion, a symbol of the Flemish movement, which is symptomatic for its more explicit attachment to the Flemish emancipation battle. (See: illustration 2) As a result, in spite of the fact that the content of the journal initially was - at times - very similar to that of Moderne School, the principles of progressive education gained a more educational meaning in the development of a "pedagogy in the framework of our Flemish national community". ${ }^{48}$

From May 1941, Vlaamsche Paedagogiek appeared monthly, with the exception of 1944, when as a result of paper shortages - only two issues appeared. Initially, the journal consisted out of four main sections, but more sections were added later on. The first section of the journal, 'General Pedagogy', informed the reader about the core principles of progressive education. These theoretical principles found their practical application in the second section, 'For and from practice' that aimed at guiding teachers in their day-to-day school routines. The third and final

\footnotetext{
${ }^{45}$ De Vroede et.al., Bijdragen tot de geschiedenis van het pedagogisch leven, 1017.

${ }^{46}$ See for instance, Bossuyt, "Ik hou zoveel van u", 5.

${ }^{47}$ We have not been able to find much further information about the front covers. We do not know exactly who made the front cover of Vlaamsche Paedagogiek. About the front cover of Moderne School, we have a bit more information. More specifically, in his Bijdragen tot de geschiedenis van het pedagogisch leven, De Vroede mention that the front cover is a "sketch of a futuristic building with four towers in greyscale", made by Ph. Reunis, S.C. See: De Vroede et.al., Bijdragen tot de geschiedenis van het pedagogisch leven, 1007.

${ }^{48}$ Ibid., 1021.
} 
sections contained, respectively, a number of book reviews and administrative announcements, relevant for teachers. In September 1941, two sections were added: 'Pedagogues, writers and artists' discussed the life and work of important protagonists of the New Education Movement, and 'From the journals' presented a summary of the most relevant and important articles in cultural, scientific and educational journals. Finally, in 1942, another three sections were added. 'Out of the history of education' discussed the roots and historical development of the BellLancaster system; the section 'Youth authors and their work' aimed to guide teachers in their choice of youth literature, and 'Announcements from the North' discussed the state of educational reform in the Netherlands. ${ }^{49}$

The first issue of the journal was published in May 1941, one year after the German attack and subsequent military occupation of Belgium. During the war, the need for educational reform was felt more strongly. According to the editorial board, the circumstances of war did not endanger the educational reform that was necessary in Flanders; quite on the contrary even. It was argued that periods of crisis had always boosted educational reforms. However, in spite of the fact that, during the interwar years, some theoretical ideas about educational renewal had been proposed, the post-war period had to be one of "practical realization". The purpose was to construct a new school, adapted to "newer didactical and pedagogical demands", built on the ruins of the old, traditional education system. ${ }^{50}$

In spite of the fact that the journal makes almost no explicit references to the war and political situation of the time, the Second World War had revealed a stronger need for moral education. For instance, during the war, moral panic arose over the increase of juvenile delinquency. It was argued that the war had exhausted youth both physically and morally, and the school had to counter that moral decay and elevate Flanders' cultural standards:

"More than ever, a life full of daily worries and a nerve wrecking rush drove people in their spare time to louder, more reckless, unruly pleasures, without true culture. Sports, cinemas and variety shows were very popular, also in those circles where one would rightly expect an urge, or even a deep devotion, for a higher cultural standard." 51

In order to do so, it was important for schools to attract teachers with an indisputable reputation. ('New') schools were in need of "optimists" who were able to put a code of honor and character against the moral nihilism that had characterized the interwar and early war years. ${ }^{52}$

As a result, especially during the war, kindergarten and primary school, in particular, became entirely directed towards the cultural elevation of the people. The instruction of 'personalities in

\footnotetext{
${ }^{49}$ Ibid., 1023.

${ }^{50}$ R. Turf, "Morgen," Vlaamsche Paedagogiek, 4 (1943): 73-74.

${ }^{51}$ Leo Roelants, "Jeugd en Toneel," Vlaamsche Paedagogiek 4 (1943): 86.

52 Turf, "Morgen": 74.
} 
service of the community' could only flourish in an educational environment that centered on the Flemish language, history, culture and reality. The principles of progressive education were seized at to demand a stronger position of 'Flanders' and the Dutch language in education. For instance, in his article series, Jan Vercammen, cantonal inspector for primary education and writer of children's books, claimed that the concentration principles could be used in order to integrate Flemish (or Dutch) in different subjects:

"Every hour needs to be a language hour, a language observation, a continuous written or oral expression. The correct use of the language is of equal importance in a mathematics class, as it is in a language class, even in writing and in exercises." 53

In other words, the ideals of progressive education gave a deeper and greater meaning to language instruction. More specifically, flamingant progressive educationalists were convinced that Dutch needed to appear as a center of interest in the curriculum. This created the opportunity to not only teach children Dutch in language courses, but to instill them with a love for the Dutch language and Flemish community, in virtually every subject. ${ }^{54}$ As such, Dutch language instruction gained a more 'educational meaning': essay-writing, for instance, did not only serve language instruction as such, but it was also believed that immaculate language skills were an important factor of a person's general life style. In short, Dutch language courses contributed to the development of the child's character and personality, and in the cultural elevation of the Flemish Volksgemeinschaft. In the same vein as Dutch language instruction, artistic education also received a more prominent place in the curriculum for the exact same reasons. The journal showed a particular interest in music education, not in the least because it could be used as an educational tool to immunize people against the perceived cultural decay. More specifically, it was argued that music education should not be included in the curriculum as the 'mechanic' teaching of songs and the teaching of superficial musical knowledge, as was the case in the traditional school. In contrast, it should be entirely dedicated to the formation of the mind and the spirit, and the nurturing of "noble ambitions in human beings". ${ }^{55}$ And, of course, music education was to be used in the establishment of a 'higher' Flemish culture ... . ${ }^{56}$

The inclusion of a school, geared towards "the life of the child that roots in the national spirit of the Flemish cultural community", demanded active education and object lessons. As a result, Vlaamsche Paedagogiek drew attention to the importance of Heimatkunde. The Heimat principle had always been attractive for progressive educationalists. In the reformed curriculum for primary education of 1936, drafted by - amongst others - Leo Roels, the Heimat principle was compared

\footnotetext{
53 Jan Vercammen, “De pedagogogiek van den stijl," Vlaamsche Paedagogiek 3 (1943): 224.

54 Jan Vercammen, “De pedagogiek van den stijl," Vlaamsche Paedagogiek 2 (1943): 29.

${ }^{55}$ Florentijn Jan Van der Mueren, "Pedagogische Sprokkelingen," Vlaamsche Paedagogiek 4 (1941): 106.

${ }^{56}$ Emiel Van Bergen, "Het muziekonderricht in de school," Vlaamsche Paedagogiek 2 (1941): 41.
} 
to the study of the environment ${ }^{57}$. However, Moderne School distinguished between the Heimat principle, and the study of local customs and folklore (Heimatkunde), which had to be avoided in the first two grades of primary school, in particular. ${ }^{58}$ In contrast, the interest of Vlaamsche Paedagogiek in the study of local customs and folklore surfaces in almost every section in the journal. For instance, in the section 'From the journals', there was a consistent attention for the journal Heemkunde (Heimatkunde). The editorial board of Vlaamsche Paedagogiek positively received their plea to support the introduction of Heimatkunde in Flanders. ${ }^{59}$ Furthermore, in the summer of 1942, Vlaamsche Paedagogiek published a report of a course of instruction that had been held in Tilburg (The Netherlands), and where the different possibilities of Heimatkunde for popular education had been discussed. ${ }^{60}$ As a result, Vlaamsche Paedagogiek was less averse of Heimatkunde (as opposed to the Heimat principle).

Also, in 'For and from practice', a section that aimed to guide teachers in their daily school practice, a number of essays and course preparations with an obvious folkloristic bias appeared about the medieval Flemish cities, such as Lier, Leuven or Diest. The written reports of those 'city walks' were presented to teachers as concentration subjects, that fitted in with several subjects, such as history or geography. ${ }^{61}$ Apart from the importance Flemish progressive educationalists attached to the study of the environment, these contributions demonstrate how the 'glorious medieval past' became a center of interest in the school. In the first three issues of 1941, for instance, the Rubens commemoration was presented as "an ideal center of interest for the higher classes of our popular school". ${ }^{62}$ This discovery of the 'old' masters and of traditional artistic genres characterized Belgian artistic circles during the interwar and war years, in general. Already in the 1930s, the Belgian artistic scene found itself in a crisis of modernity, and advocated a return to healthy values and norms in order to prevent art from decadence. As Virginie Devillez has argued, this crisis of modern art is inseparable from the negative feeling of a part of the population who had paid for the excesses of the roaring twenties. Within that particular societal context a feeling of moral and cultural malaise developed that was justified by a way of life to which the individual could no longer identify itself with. ${ }^{63}$

\footnotetext{
${ }^{57}$ Depaepe et al. have defined the study of the environment as thematic subjects that fitted in with the environment of the child. See: Depaepe, Orde in Vooruitgang, 97.

58 Bossuyt, "Ik hou zoveel van u", 147.

59 See, for instance, Vlaamsche Paedagogiek 3 (1943): 72.

60 P.L. Van Eck Jr., “Onderwijsvernieuwing," Vlaamsche Paedagogiek 8/9 (1942): 233-4.

${ }^{61}$ De Vroede et.al., Bijdragen tot de geschiedenis van het pedagogisch leven, 1022.

62 Norbert Van Schoor, "De Rubens-herdenking. Een uitgelezen belangstellingspunt voor de hoogere klassen onzer volksschool," Vlaamsche Paedagogiek 1/2/3 (1941).

${ }^{63}$ Virginie Devillez, "Les peintres belges dans la tourmente. Du krach économique à la Seconde Guerre mondiale," Bijdragen tot de Eigentijdse Geschiedenis 10, no. 3 (1997) : 38-40.
} 
In Vlaamsche Paedagogiek, the glorious medieval past, in particular, became the beacon on which the Flemish community feeling could again grow and flourish, since Flanders had gained its power in the shadow of great historical figures, such as Rubens. Vlaamsche Paedagogiek glorified the Flemish past and artists, precisely because they represented the values of the ideal Volksgemeinschaft. Norbert Van Schoor, for instance, praised Rubens for his Flemishness, his patriotism, religious devotion, honesty, sense of duty, his honor and love for life, his order, intelligence and work ethics. ${ }^{64}$ The attention for Rubens in the classroom could, "by intense sympathy with the great among our people, create an atmosphere that could evoke a real and true feeling of national solidarity (...)" ${ }^{65}$ The connection between the study of the past and the feeling of national solidarity certainly was not new. Marnix Beyen, for instance, has pointed out that even during the interwar period, cultural life centered on the past, and bore a strong traditionalist stamp. He added that this retrogressive ('rückwärtsgewandte') culture appealed to the public that focused on a glorious past, rather than on an uncertain future. ${ }^{66}$

Also in Moderne School, it was argued that he study of the environment could trigger pupils' patriotism. ${ }^{67}$ Vlaamsche Paedagogiek, however, made it more explicit that the ultimate purpose of education was "to create a national cultural unity, a Flemish cultural community", consisting of "individual, harmonically developed in mind and spirit, rooted in the Flemish past and consciously directed towards a brighter future" .68 Yet, Flemish progressive educationalists continued to be concerned about the possible "urbanism, regionalism or chauvinism" that could result from the emphasis on patriotism. ${ }^{69}$ In spite of the fact that the school needed to be more oriented towards Flemish or even local history and geography, it could not become isolated from the wider world. The outbreak of the Second World War, that had caused a shock wave in the entire world, was a symptom of the increased globalization. As a result, the "necessary commitment to one's own Nation and People" continued to go hand in hand with an involvement in the wider geographical sphere. $^{70}$

\footnotetext{
64 Van Schoor, "De Rubens-herdenking. Een uitgelezen belangstellingspunt voor de hoogere klassen onzer volksschool," Vlaamsche Paedagogiek 2 (1941): 66-7.

${ }^{65}$ Norbert Van Schoor, "De Rubens-herdenking. Een uitgelezen belangstellingspunt voor de hoogere klassen onzer volksschool," Vlaamsche Paedagogiek 3 (1941): 96.

${ }^{66}$ Marnix Beyen, "Van Brunclair tot Peleman. Cultureel onderhandelen in bezettingstijd," in Verbrande schrijvers. 'Culturele' collaboratie in Vlaanderen (1933-1953), ed. L. De Vos, Y. T'Sjoen and L. Stynen (Gent: Academia Press, 2009), 33.

${ }^{67}$ Bossuyt, "Ik hou zoveel van u", 148.

68 Van Bergen, "Het muziekonderricht": 41.

${ }^{69}$ Van Eck Jr., "Onderwijsvernieuwing": 234.

70 Turf, "Morgen": 74.
} 


\section{Vlaamsche Paedagogiek and its relationship with fascist pedagogy}

As the previous section documents, some aspects of the discourse of Vlaamsche Paedagogiek shows remarkable similarities with fascist pedagogical principles. As Depaepe, Simon and Van Gorp have argued, the inclusion of the progressive educational ideal of self-development in service of the community brought educational reformers, such as Verheyen, close to other normative pedagogical theories and ideologies, such as Catholic or fascist pedagogy. ${ }^{71}$ Not only did progressive education underline the 'totality' of education, the ascendance of the community over the individual, but also the emphasis on the formation of the child's character and personality sounded very similar to fascist pedagogy. ${ }^{72}$ This emphasis on the importance of character and personality formation in the school had existed since the gay twenties, but it was reinforced by the war. In order to turn the tide, order and discipline were never far away. In spite of the fact that, in their educational reform discourse, the free development of the child was put central, discipline was inevitable. It was believed that there were two enemies of educational reform: those who wanted to commercialize it, and those who argued for a total laisser-faire in the classroom. ${ }^{73}$ Verheyen himself criticized teachers in traditional education who could not handle the children in their classrooms. Order, based on authority and healthy discipline were perceived as a necessary condition to give children the space to freely develop.

In essence, the Flemish pedagogy was geared towards the creation of a "pedagogical order, that has a place for everything and puts everything in place". ${ }^{74}$ In contrast to the "educational dummies ${ }^{75}$ that were used in traditional education to force discipline onto the child, the circumstances of war urged the educator to search for adapted means to permeate the life of the child with discipline. ${ }^{76}$ In contrast to the traditional methods of punishment and rewarding, the editors and authors of Vlaamsche Paedagogiek proposed to use practical exercises or art education as tools to make children internalize discipline. ${ }^{77}$ The plea for a natural feeling of discipline and good behavior did not go beyond rhetoric Spielerei. Instead of discipline, the authors and editors of Vlaamsche Paedagogiek frequently used 'order', to point to (more or less) the same thing. In spite of the importance of the free development and expression of the child, it was suggested that children needed to be steered in the right direction that gave them the impression of free choice.

\footnotetext{
${ }^{71}$ Depaepe, Simon and Van Gorp, 'Pedagogische Praat', 182.

72 Ibidem.

73 Karel Roels, "Aanvankelijk leesonderrricht," Vlaamsche Paedagogiek 3 (1943): 60.

74 Jan Vercammen, Vlaamsche Paedagogiek 6 (1943): 130.

75 Ibid.: 134.

${ }^{76}$ Florentijn Jan Van der Mueren, "Pedagogische sprokkelingen," Vlaamsche Paedagogiek 5 (1941): 135.

77 Ibid.: 136.
} 
In other words, strict guidance of the child was not only necessary, but, ideally, it was also voluntarily accepted. ${ }^{78}$

In spite of those shared principles, however, the journal abstained from commenting on National Socialism, the war or the German occupation. Before the war, however, Moderne School had published quite a few articles, commenting on National Socialist pedagogues, such as Ernst Krieck, or the New Order and its educational principles. ${ }^{79}$ During the war, explicit references to or comments about the war, the New Order or politics became a complicated issue, and Vlaamsche Paedagogiek never defined its position against the New Order clearly. Some educationalists who had been involved in the VOV during the interwar years and that radically chose to collaborate with the German occupier during the war, such as De Vleeschauwer or Strauven, never wrote for Vlaamsche Paedagogiek. In his autobiography, Leo Roels, for instance, claimed to have avoided contacts with Strauven as soon as he had revealed his sympathies for Germany immediately after the German attack in May 1940. ${ }^{80}$

Generally, the journal consisted of a heterogeneous group of people, who did not clearly define their position towards the occupier more often than those who did. Only some of the regular contributors to the journal cherished overt sympathies for the New Order. Florentijn Jan Van der Mueren, for instance, who authored many articles in Vlaamsche Paedagogiek was not only a committed flamingant who supported the Flemish cultural emancipation battle, but he was also politically active during the war as an alderman for Public Education and Fine Arts in the city of Leuven. Allegedly, he had sympathies for the Verbond van Dietsche Nationaal-Solidaristen (Union of Diets National Solidarists, Verdinaso) ${ }^{81}$, a fascist political organization that was active in the Low countries during the 1930s, in particular. ${ }^{82}$ Also, Emiel Van Bergen who wrote articles for Vlaamsche Paedagogiek about music education, in particular, cherished fascist sympathies. Already during the First World War, Van Bergen had been engaged in several aktivistische (collaborating) organizations, such as Jong Vlaanderen or the Raad van Vlaanderen. He was a strong supporter, not only of a cultural independent Flanders, but also a politically independent

\footnotetext{
78 Jan Vercammen, "Pedagogiek van den stijl," Vlaamsche Paedagogiek 5 (1943): 106.

79 Bossuyt, "Ik hou zoveel van u", 155-162.

80 Roels, Twintig jaar boeman, 195-196.

${ }^{81}$ For more information about the Verdinaso, see, for instance, Jan Creve, Recht en trouw: de geschiedenis van het Verdinaso en zijn milities (Antwerpen: Soethoudt, 1987); Bruno De Wever, Verdinaso (Bruxelles: André Versaille, 2008); Maurits Cailliau, Het Verdinaso, antisemitisme und kein Ende? (leper: Studiecentrum Joris van Severen, 2009).

82 Kamiel Cooremans, "Florentijn Jan van der Mueren," Jaarboek van de Maatschappij der Nederlandse Letterkunde, 1973, 181-188. (Online available via http://www.dbnl.org/tekst/ jaa003197301 01/ jaa003197301 $010020 . p h p)$; Godfried Kwanten, "Moeders krullenbol (1906-juni 1929)," in Ast Fonteyne 1906-1991. Een kwestie van stijl, ed. P Anthonissen et al. (Leuven: Universitaire Pers Leuven, 1999), 34.
} 
Flemish nation. During the Second World War, he championed the development of a Germanic culture, and criticized the individualism of modernity. ${ }^{83}$

After the war, Roels and Verheyen distanced themselves from these figures and downplayed their involvement in Vlaamsche Paedagogiek, in spite of the fact that they had been working together with some convinced flamingants and New Order sympathizers during the interwar period in the lap of Moderne School. During the 1930s, Moderne School explicitly praised the works of Frans Daels, or Cyriel Verschaeve, two well-known Flemish political collaborators. ${ }^{84}$ However, from the very start in 1941, the first page of the journal mentioned that each author was responsible for their own contributions, which begs the question as to why Roels and Verheyen got involved in a journal that they did not fully support. Perhaps, their involvement should be explained on pragmatic, rather than ideological grounds. Apart from being one of the chief editors of Vlaamsche Paedagogiek, Verheyen was a professor at the Higher Institute for Education (Hoger Instituut voor Opvoedkunde) of the State University of Ghent. He was somewhat looked down on by his colleagues at the Higher Institute for Educational Sciences of the University of Ghent because he was a 'man of practice', and had never obtained a doctorate. ${ }^{85}$ It is possible that Verheyen therefore held all options open not to risk his career, or even to advance it.

In principle, Verheyen was a pacifist and on those grounds Moderne School condemned National Socialism (as well as Communism, by the way) as an extreme form of nationalism. ${ }^{86}$ The message and contributors of Vlaamsche Paedagogiek also fundamentally differed from those of the journal of the Dietsche Opvoedkundige Beweging that rallied itself behind Nazism, and advocated a reform of the Flemish education system along Germanic lines. ${ }^{87}$ In spite of the close contacts between Verheyen and Roels, and some active members of the collaboration, they would stick to their 'progressive' education discourse. ${ }^{88}$

\section{Conclusion}

The aim of this article has been to document the position of the Flemish progressive education movement, rallied around Leo Roels and Jozef-Emiel Verheyen, before and during the Second World War, by focusing on the journal Vlaamsche Paedagogiek. This paper found that the journal

\footnotetext{
${ }^{83}$ Nico Wouters, "Bergen, Emiel van," Nieuwe Encyclopedie van de Vlaamse Beweging, 463-464.

${ }^{84}$ Bossuyt, "Ik hou zoveel van u", 164.

${ }^{85}$ Some of his colleagues had issues with the fact that, initially, he was responsible for the development of an education institute where he was a student at the same time. Depaepe, Simon and Van Gorp, "Pedagogische Praat," 190.

${ }^{86}$ Bossuyt, "Ik hou zoveel van u", 187.

87 See: Björn Mervilde, "Opvoeden in een dwangbuis? De Vlaams-nationalistische pedagogiek van de D.O.B. als prototype van de normatieve pedagogiek (1930-1945)" (master's thesis, Katholieke Universiteit Leuven, 2003); De Clerck, 'The Dietsch Opvoedkundige Beweging'.

${ }^{88}$ For Verheyen, see: Depaepe, Simon and Van Gorp, "Pedagogische Praat," 184.
} 
connected explicitly and directly with the basic demands of the Flemish movement. More specifically, the journal demanded more attention for the Dutch language, Flemish history and art in school, with the intention of creating an independent Flemish 'higher' culture, and with a view on the cultural and moral 'elevation' of the Flemish people. For Vlaamsche Paedagogiek, the school not only rooted in the Volksgemeinschaft ${ }^{89}$, but it also had to be permeated by the Flemish character.

In terms of content, the journal did show many similarities with that of Moderne School and - to a lesser degree - the Schoolblad voor Vlaanderen. Unsurprisingly, perhaps, many of the authors of Vlaamsche Paedagogiek had also been active as contributors or members of the editorial board of Moderne School during the interwar years, or had contributed to the 1939 edition of the Paedagogische Encylopaedie (Pedagogical Encyclopedia), edited by Jozef Emiel Verheyen and Rommert Casimir ${ }^{90}$. As a result, Vlaamsche Paedagoiek should be understood with the context of a more general evolution towards Flemish cultural emancipation that had taken place in Flemish progressive educational circles since the 1920s. In spite of the fact that the journal was a continuation of earlier education periodicals, however, its engagement for the Flemish cultural emancipation battle was more explicit. The journal reads as a plea to use the school as a tool in the construction of an independent Flemish cultural community, an idea that was popular in Catholic, Flemish milieus, in particular ${ }^{91}$. The moral elevation of the people, via the school, was considered imperative to this Flemish cultural emancipation process. The school was an institution to civilize and culturally develop the child, as Flanders would never be able to enjoy the treasures of its rich past, or even exist without foreign cultural influences, if the young Flemish boy and girl were not culturally developed, disciplined and civilized. ${ }^{92}$

By documenting the gradual evolution of the Flemish progressive education movement, which gathered around Verheyen and Roels, towards a more explicit engagement for the Flemish Volksgemeinschaft, this article supports the observation that there was a high degree of paradigmatic unity in the education landscape during the 1930 s and early $1940 s^{93}$. This is

\footnotetext{
89 At this point, it is important to note that the word Volksgemeinschaft was not explicitly used in Vlaamsche Paedagogiek. It mainly refered to the "eigen Vlaamsche volkswezen", which we have translated as Volksgemeinschaft.

${ }^{90}$ Rommert Casimir was a Dutch educationalist and reformer. During the interwar year, Casimir was extraordinary professor of Educational Sciences and Psychology at the University of Leiden. For more details on the life and work of Casimir, see, for instance: Paul Gerretsen, "Rector Rommert Casimir in tweevoud," Jaarboek Geschiedkundige Vereniging Die Haghe (2009): 2015-220.

${ }^{91}$ See: Lode Wils, Honderd jaar Vlaamse Beweging. Geschiedenis van het Davidsfonds in en rond Wereldoorlog II (Leuven: Davidsfonds, 1989), 192-193.

92 Peter Anthonissen, "'Met het stokje tussen de tanden". Ast Fonteyne als voordrachtkunstenaar en als leraar welsprekendheid (1933/1945-1971)," in Ast Fonteyne, 166.

${ }^{93}$ For more information about this issue, see: Marc Depaepe, De pedagogisering achterna. Aanzet tot een genealogie van de pedagogische mentaliteit in de voorbije 250 jaar (Leuven: Acco, 1998).
} 
illustrated by the multiple similarities between the progressive and fascist educational discourses. A more longitudinal perspective, and particular attention to pre-war developments, is important, as it illustrates how seemingly contradictory pedagogical ideas (e.g. the combination of a longing for a child-centered pedagogy, equally founded on authority, discipline and order) came together in one journal. Presumably, this was in some part the result of the fact that the Flemish Educational Association did not represent a particular educational or political movement. As a result, Vlaamsche Paedagogiek, as the heir of Moderne School and the Schoolblad voor Vlaanderen, had to appeal to a diverse readership, since it brought together educators and teachers from different ideological corners. 